\title{
제 950차 OECD 개발원조위원회(DAC) 정례회의
}

\section{I. 회의 개요}

제950차 $\mathrm{OECD}$ 개발원조위원회(DAC) 정례회의가 2012년 7월 12 일 $\mathrm{OECD}$ 본부에서 개최됨.

\section{II . 주요내용}

- 2011-12 DAC 작업 및 예산 프로그램 이행현황, DAC 개발재원 통계 작업반회의(6.5-7) 및 원조효과작업반회의(6.28-29) 결과에 대해 보고를 받고, 2013-14 DAC 개발협력정책 집행검토 레퍼런스 가이드, DAC Facilitator Group 설치 운영 규정 및 DAC 거버넌스 네 트워크(DAC/GOVNET) 이 제출한 개발협력, 책임성 및 민주적 거버넌스에 관한 오리엔테 이션과 원칙에 관한 보고서를 채택하였음.

- Atwood DAC 의장은 DAC가 OECD내 독립적인 상설위원회로서 기능하면서도 군소 $\mathrm{DAC}$ 회원국 출신의 유능한 인사도 $\mathrm{DAC}$ 의장을 수임할 수 있도록 예산부담을 경감시켜주는 별첨 $\mathrm{DAC}$ 의장 재정지원 및 선출개혁방안을 제안하고, 7 월 31일까지 회원국들이 입장을 알려줄 것을 요청함.

\section{III. 관찰 및 평가/건의}

- 금번 회의에서 Atwood DAC 의장과 참석자들은 지난 6개월 동안 글로벌 파트너십 출범을 위한 협의과정이 포용적으로 이루어져 다양한 개발주체들이 참여하는 파트너십이 출범되었 다고 평가하고, $\mathrm{DAC}$ 차원에서 개발협력 성과제고를 위해 계속 주도적 역할을 수행해야 함 을 강조함.

- 자발적 기여금을 통한 $\mathrm{DAC}$ 의장 펀드 설치관련, 동 방안이 $\mathrm{DAC}$ 의 특수성(독립 상설위원회 로서 34 개 $\mathrm{OECD}$ 회원국 중에서 24 개 국가만 참여) 및 $\mathrm{DAC}$ 의장의 독립성 보장 측면에서 펀드를 통한 지원이 현재로선 가장 현실적인 방안으로 사료됨. 